\author{
Ryszard P. Krawczyk*
}

\title{
Nadzór nad działalnością samorządu terytorialnego w Polsce - aktualne problemy
}

\section{Samorząd - koncepcja}

Rzeczpospolita Polska przyjmuje koncepcję państwową samorządu wywodząca swój byt z pozytywizmu prawniczego. Oznacza to, że samorząd jest wytworem państwa, które dobrowolnie rezygnuje z wykonywania niektórych swoich zadań w zakresie administracji publicznej. Istota samorządu polega więc na zwierzchnim wykonywaniu przysługujących mu praw, przekazanych przez państwo.

\section{Konstytutywne cechy samorządu terytorialnego}

Definicję legalną pojęcia samorządu terytorialnego można wywieść z art. 3 ust. 1 Europejskiej Karty Samorządu Lokalnego ${ }^{1}$ oraz art. 3 ust. 1 Europejskiej Karty Samorządu Regionalnego. Akty te wskazują, że samorząd terytorialny oznacza prawo i rzeczywistą zdolność społeczności lokalnych (ponadlokalnych, regionalnych), w granicach określonych prawem, do kierowania i zarządzania zasadniczą częścią spraw publicznych na ich własną odpowiedzialność i w interesie mieszkańców przy zachowaniu zasady subsydiarności.

Ustawodawca konstytucyjny nie definiuje wprost pojęcia samorządu terytorialnego, ale w poszczególnych artykułach ustawy zasadniczej zawiera elementy konstrukcyjne umożliwiające jej sformułowania. Artykuł 16 ust. 2 Konstytucji RP stanowi, że ,samorząd terytorialny uczestniczy w sprawowaniu władzy publicznej. Przysługującą mu w ramach ustaw istotną część zadań publicznych samorząd wykonuje w imieniu własnym i na własną odpowiedzialność". Z art. 163 Konstytucji wynika, że ,samorząd terytorialny wykonuje zadania publiczne nie zastrzeżone przez Konstytucję lub ustawy dla organów innych władz publicznych".

* Dr, Katedra Prawa Konstytucyjnego Uniwersytetu Łódzkiego.

${ }^{1}$ Dz. U. z 1994 r., nr 124, poz. 607 ze sprost. 


\subsection{Pojęcie nadzoru}

Pojęcie nadzoru pojawiło się w epoce liberalnego państwa prawnego i związane jest z procesem decentralizacji władzy publicznej ${ }^{2}$. Za wyrokiem Trybunału Konstytucyjnego z dnia 5 października 1994 r. możemy stwierdzić, że przez „nadzór należy rozumieć określone procedury, dające odpowiednim organom państwowym, wyposażonym w stosowne kompetencje, prawo analizowania i ustalania stanu faktycznego, jak też modyfikowania działań organu nadzorowanego"3.

$\mathrm{W}$ administracji publicznej o charakterze strukturalno-organizacyjnym lub funkcjonalno-organizacyjnym występują dwa rodzaje nadzoru: nadzór hierarchiczny (dyrektywny) i nadzór weryfikacyjny. Ten pierwszy charakterystyczny jest dla modelu administracji scentralizowanej i określany jest przez nadrzędność hierarchiczną oraz upoważnia do „sprawowania kierownictwa nad działalnością organów niższego rzędu za pośrednictwem dyrektyw administracyjnych". Ten drugi występuje w modelu administracji zdecentralizowanej charakteryzowanej przez stosunki nadrzędności i podporządkowania o charakterze decentralistycznym W literaturze przedmiotu występuje jeszcze pojęcie nadzoru policyjnego (nadzoru administracyjnego) opartego na przepisach prawa materialnego. Jego istotą jest oparcie działań nadzorczych na kryterium przedmiotowym. Obejmuje on ochronę wartości chronionych prawnie, takich jak bezpieczeństwo publiczne, porządek publiczny, zdrowotność obywateli.

\subsection{Podstawy prawne nadzoru nad samorządem terytorialnym}

1. Artykuł 171 ust. 1 Konstytucji RP stanowi, ze „działalność samorządu terytorialnego podlega nadzorowi z punktu widzenia legalności”. Artykuł 8 EKSL wskazuje, że wszelka kontrola administracyjna społeczności lokalnych dokonywana jest wyłącznie w sposób oraz w przypadkach przewidzianych w Konstytucji lub ustawie i powinna mieć na celu jedynie zapewnienie przestrzegania prawa i zasad konstytucyjnych. Z EKSL wynika również inna istotna zasada nadzoru nad korporacjami samorządu terytorialnego - zasada proporcjonalności, wskazująca na zachowanie właściwej proporcji między stosowanymi środkami nadzoru a chronionymi przez ten nadzór wartościami i interesami.

Nadzór nad samorządem terytorialnym jest jednym z elementów wyznaczających prawne granice samodzielności samorządu terytorialnego. Inne istotne czynniki to osobowość prawna jednostek samorządu terytorialnego, dysponowa-

${ }^{2}$ A. Filipowicz, Pojęcie i funkcje nadzoru w administracji, Wrocław 1984, s. 216; B. Dolnicki, Nadzór nad samorzadem terytorialnym, Katowice 1993, s. 62 i n. Na temat pojęcia decentralizacji patrz także: wyrok TK z dnia 18 lutego 2003 r., K 24/02; OTK 2003, nr 2, poz. 11.

${ }^{3}$ W 1/94, OTK 1994, nr 2, poz. 47. 
nie mieniem komunalnym i innymi prawami majątkowymi, odpowiedzialność za podejmowane decyzje oraz gwarancje istnienia ochrony sądowej praw jednostek samorządu terytorialnego. Koncepcja nadzoru wprowadzona do polskiego ustawodawstwa charakteryzuje się jednolitością rozwiązań dla wszystkich trzech jego szczebli.

2. Wszystkie ustawy ustrojowe dotyczące samorządu terytorialnego ${ }^{4}$ powtarzają treść art. 171 ust. 2 Konstytucji $R P$ stwierdzając, że organami nadzoru nad działalnością komunalną są Prezes Rady Ministrów i wojewodowie, a w zakresie spraw finansowych - regionalne izby obrachunkowe ${ }^{5}$. Wyliczenie to wskazuje, że nadzór nad działalnością komunalną wykonywany jest przy zachowaniu zasady rozdzielenia kompetencji nadzorczych. Uprawnienia nadzorcze w stosunku do samorządu terytorialnego posiada również Sejm, choć nie jest on organem nadzoru Zgodnie z art. 171 ust. 3 Konstytucji, Sejm na wniosek Prezesa Rady Ministrów, może rozwiązać organ stanowiący samorządu terytorialnego, jeżeli organ ten rażąco narusza Konstytucję lub ustawy.

3. Konstytucja RP w art. 171 ust. 1 stwierdza, że działalność samorządu podlega nadzorowi z punktu widzenia legalności.

\subsection{Organy nadzoru nad samorządem terytorialnym - aktualne problemy}

1. Konstytucja $R P$ w preambule wskazuje, że w działaniu instytucji publicznych należy zapewnić rzetelność i sprawność. To postanowienie konstytucji nie przedkłada się wprost na istniejącą w Polsce koncepcje nadzoru, w ograniczonym natomiast stopniu kryterium rzetelności występuje wyłącznie jako kryterium kontrolne w kontrolach prowadzonych wobec samorządu terytorialnego. Brak standaryzacji usług publicznych podczas wykonywania zadań oraz rzetelnej oceny ich kosztów powoduje coraz większe kontrowersje na linii rząd (jako zleceniodawcy zadań publicznych) - jednostki samorządu terytorialnego (jako wykonawcy zadań zleconych). Koncepcja nadzoru i kontroli nad samorządem terytorialnym nie jest nakierowana na zapewnienie sprawności działania jednostek samorządowych, a w zasadzie na przestrzeganie prawa - co wydaje się być oczywiste, z tym jednak zastrzeżeniem, że w wielu przypadkach prawo samorządowe jest niespójne. Instytucje dokonujące kontroli samorządu działają według różnych kryteriów kontroli. Klasycznym przykładem jest kontrola wykonywana wobec

${ }^{4}$ Ustawa z dnia 8 marca 1990 r. o samorządzie gminnym (tekst jedn. Dz. U. z 2013 r., poz. 594 ze zm.; dalej: u.s.g.); ustawa z dnia 5 czerwca 1998 r. o samorządzie powiatowym (tekst jedn. Dz. U. z 2013 r., poz. 595 ze zm.; dalej: u.s.p.) i ustawa z dnia 5 czerwca 1998 r. o samorządzie województwa (tekst jedn. Dz. U. z 2013 r., poz. 506 ze zm.; dalej: u.s.w.).

${ }_{5}^{5}$ Poza konstytucyjną konstrukcją nadzoru należy widzieć uprawnienia ministra spraw zagranicznych, który na podstawie art. 77 ustawy o samorządzie województwa wyraża zgodę na zawarcie umowy o współpracy regionalnej. 
samorządu przez NIK oparta na kryterium legalności, gospodarności i rzetelności oraz kontrola wykonywana przez regionalne izby obrachunkowe oparta w przypadku zadań własnych na kryterium legalności i rzetelności, w przypadku zaś zadań zleconych dodatkowo na kryterium celowości i gospodarności. Jest oczywiste, że przy tak zróżnicowanych kryteriach kontroli trudne jest, jeżeli wręcz niemożliwe, współdziałanie instytucji kontrolnych. Osobnym problemem pozostaje racjonalność upoważnienia dwóch instytucji kontrolnych do wykonywania kontroli wobec samorządu terytorialnego.

2. Obowiązujące przepisy prawa nie nakładają na organy wykonawcze samorządu przedstawiania raportów z przeprowadzonych kontroli oraz wskazywania radnym podjętych działań naprawczych. Ten stan rzeczy nie sprzyja podnoszeniu efektywności zarządzania środkami publicznymi. Niewątpliwie ustawodawca zdaje sobie sprawę z konieczności sprawnego działania również $\mathrm{w}$ gospodarce finansowej samorządu terytorialnego. Wyrazem tego jest brzmienie art. 44 ust. 3 pkt. 1 ustawy z dnia 27 sierpnia 2009 r. (dalej: u.f.p.) ${ }^{6}$ o finansach publicznych. Problemem - dla części przedstawicieli doktryny, jest jednak to, że organy wykonujące kontrolę nad samorządem terytorialnym nie mogą jej wykonywać z punktu widzenia celowości. A więc pytanie „kto jest w stanie określić optymalność zastosowanych metod i środków realizacji?" - pozostaje w wielu przypadkach otwarte $^{7}$. Autor niniejszego opracowania nie jest zwolennikiem tezy ograniczania samodzielności jednostek samorządu terytorialnego (dalej: j.s.t.) poprzez dokonywanie przez organy państwa ocen z punktu widzenia celowości. W gospodarce j.s.t. stosowane są rozwiązania, które ze względu na swoją celowość, efektywność mogą budzić uzasadnione wątpliwości. Wykonywanie zadań na podstawie umowy in house, partnerstwo publiczno-prywatne, tzw. leasing zwrotny zawsze może prowadzić do pytania o rachunek ekonomiczny przedsięwzięcia i jego legalność w świetle obowiązującego prawa. Niewątpliwie jednak ujawniane przez organy kontroli i nadzoru przypadki rażącej niegospodarności w gospodarce j.s.t. winny spotykać się z bardziej zdecydowaną reakcją prokuratury.

3. Problemem, który nie został dostatecznie rozwiązany przez ustawodawcę jest brak wyraźnego rozgraniczenia kompetencji nadzorczych między wojewodów - jako organy nadzoru ogólnego, a regionalne izby obrachunkowe, jako organy nadzoru wyspecjalizowanego. Istniejące rozgraniczenie kompetencji nadzorczych między wojewodów a regionalne izby obrachunkowe nie ma charakteru wyczerpującego. Artykuł 11 ustawy z dnia 7 października 1992 r. o regionalnych izbach obrachunkowych (dalej: ustawa o r.i.o.) wskazuje kognicję nadzorczą izb w siedmiu kategoriach spraw, których mogą dotyczyć uchwały i zarządzenia podejmowane przez organy jednostek samorządu terytorialnego. Ustawodawca

\footnotetext{
${ }^{6}$ Tekst jedn. Dz. u. z 2013 r., poz. 885 ze zm.

7 Por. E. Wojciechowski, A. Podgórniak-Krzykacz, Z. Dolewka, M. Wojciechowski, Samorząd terytorialny w Polsce. Raport, Łódź 2014, s. 64.
} 
zwykły, ustanawiając w art. 11 ustawy o r.i.o. katalog spraw, w których właściwość nadzorczą posiadają regionalne izby obrachunkowe nie zdecydował się na określenie, że nadzór ten wykonywany jest „w zakresie spraw finansowych”. Intencja ustawodawcy wydaje się tu oczywista - w tym stanie rzeczy istnieją kategorie uchwał j.s.t., które mieszczą się „w zakresie spraw finansowych”, a należą do kognicji nadzorczej wojewodów - przykładowo uchwały j.s.t. dotyczące wynagrodzeń wójtów, burmistrzów, prezydentów miast czy też uchwały dotyczące diet dla radnych. W związku z tym, w praktyce oraz w doktrynie przyjęto zasadę, że jeżeli ustawodawca nie przypisał danej materii organowi nadzoru wyspecjalizowanego, to wówczas właściwość nadzorczą posiada organ nadzoru ogólnego czyli wojewoda ${ }^{8}$. Wydaje się jednak, że ten stan rzeczy jest konsekwencją braku determinacji w konsekwentnym reformowaniu spraw ustrojowych w państwie oraz zwycięstwem koncepcji utrzymywania w jak najszerszym zakresie nadzoru politycznego.

Ten brak woli politycznej do uregulowania rozdziału kompetencji nadzorczych między wymienione organy powoduje, że w dalszym ciągu mamy do czynienia z niepewnością w zakresie kognicji nadzorczej. W praktyce działania organów samorządu wyraża się to m.in. tym, że podejmowane uchwały i zarządzenia, co do których brak pewności właściwości nadzorczej odpowiedniego organu przesyłane są do zbadania obu organom nadzoru. Natomiast w sytuacji, kiedy pojawia się nowa kategoria uchwał lub zarządzeń organów j.s.t. oba organy nadzoru muszą określić swoja właściwość nadzorczą. Brak porozumienia w tym zakresie może rodzić powstawanie sporów o właściwość, dla których właściwym organem do ich rozstrzygnięcia pozostaje minister administracji i cyfryzacji ${ }^{9}$. Można również zauważyć, że w sytuacji nowych uchwał j.s.t., które nie mieszczą się wprost w dyspozycji art. 11 ustawy o r.i.o., a w ocenie kolegiów r.i.o. są

${ }^{8} \mathrm{Na}$ temat ewolucji uprawnień nadzorczych r.i.o.: S. Srocki, Ewolucja kompetencji nadzorczych regionalnych izb obrachunkowych, [w:] M. Stec (red.), Regionalne izby obrachunkowe. Charakterystyka ustrojowa i komentarz do ustawy, Warszawa 2010, s. 90-117; R.P. Krawczyk, Efektywność i skuteczność nadzoru nad samorządem terytorialnym, „Finanse Komunalne” 2014, nr 10, s. 7-9.

9 Tego rodzaju przykładem była nowelizacja w 2011 r. (Dz. U. nr 230, poz. 1373) ustawy z 13 września 1996 r. o utrzymaniu czystości i porządku w gminach, która to wprowadziła kilkanaście nowej kategorii uchwał organu stanowiącego j.s.t. Część z tych uchwał mieściła się w dyspozycji przepisu art. 11 ust. 1 pkt 5 ustawy o r.i.o. Krajowa Rada Regionalnych Izb Obrachunkowych, mając na uwadze ujednolicenie orzecznictwa w dniu 27 września 2012 podjęła uchwalę nr 10/2012, w której wymieniła uchwały podejmowane przez organy j.s.t. na podstawie ustawy o utrzymaniu czystości i porządku w gminach podlegające kognicji nadzorczej kolegiów r.i.o. Niestety wojewoda małopolski uznał swoją właściwość w stosunku do uchwał obejmujących wszystkie kategorie spraw z zakresu utrzymania czystości i porządku w gminach. Minister właściwy do spraw administracji publicznej nie raczył zauważyć wystąpienia pozytywnego sporu o właściwość nadzorczą. Stanowisko wojewody zostało zmienione dopiero w 2014 r. wskutek rozstrzygnięć sadów administracyjnych, w których dokonano rozgraniczenia kompetencji nadzorczych. 
uchwałami „z zakresu spraw finansowych”, właściwość nadzorcza izb ustalana jest na podstawie art. $171 \mathrm{w}$ związku z art. 8 ust. 2 Konstytucji $R P$.

4. Jednostki samorządu terytorialnego stosunkowo rzadko zaskarżają rozstrzygnięcia nadzorcze do sądów administracyjnych. Niewątpliwie jedną z istotnych przyczyn tego stanu rzeczy są dość odległe terminy jakie wyznaczane są przez sądy administracyjne na rozpatrzenie skarg. Tylko w przypadku skargi na rozstrzygnięcie nadzorcze dotyczące uchwał budżetowych j.s.t korzysta z preferencji wyznaczenia przez WSA w ciągu $30 \mathrm{dni}$, daty rozpatrzenia skargi. Nie oznacza to oczywiście, że w ciągu 30 dni sprawa zostanie rozpatrzona przez sąd administracyjny. Ten stan rzeczy musi zniechęcać do częstszego korzystania z ochrony swej samodzielności.

5. Nie upatrywałbym natomiast ograniczenia konstytucyjnej zasady ochrony sądowej samodzielności samorządu terytorialnego (art. 165 Konstytucji RP) w prawie odmowy ochrony przez sądy administracyjne orzeczeń RIO lub wojewodów w sprawie uchybień kwalifikowanych jako nieistotne naruszenie pra$\mathrm{wa}^{10}$. Orzeczenia tego typu od samego początku nie tylko w świetle ustawy z dnia 30 sierpnia 2002 r. - Prawo o postepowaniu przed sąami administracyjnymi ${ }^{11}$, ale również ustaw samorządowych, nie były traktowane jako rozstrzygnięcia nadzorcze $^{12}$. Stanowisko to, jako można zauważyć, dość konsekwentnie prezentowane jest $\mathrm{w}$ orzecznictwie sądów administracyjnych - postanowienie NSA z dnia 21 lutego 2007 r. $^{13}$, postanowienie WSA w Poznaniu z dnia 8 lipca 2009 r. ${ }^{14}$, postanowieniu WSA w Kielcach z dnia 31 października 2011 r. ${ }^{15}$, postanowieniu WSA w Białymstoku z dnia 27 czerwca 2012 r. ${ }^{16}$ Postulowane w doktrynie - na szczęście w sposób jednostkowy - stanowisko objęcia kognicją kontrolną sądów administracyjnych rozstrzygnięć o nieistotnym naruszeniu prawa ${ }^{17}$ nie wzmocni samodzielności samorządu terytorialnego, poważnie wydłuży oczekiwanie na rozstrzygnięcie sądu oraz dodatkowo będzie dezawuować przedmiot sporu.

6. W ustawach ustrojowych dotyczących samorządu przewiduje się również środki nadzoru w postaci nadzwyczajnej ${ }^{18}$. Obowiązujące przepisy tego typu roz-

${ }^{10}$ Tak: J. Bober i in.,, Narastajace dysfunkcje, zasadnicze dylematy. Konieczne działania. Raport o stanie samorzadności terytorialnej w Polsce, Kraków 2013, s. 26.

11 Tekst jedn. Dz. U. z 2012 r., poz. 270 ze zm.

12 Tak: W. Chróścielewski, Z. Kmieciak, Postępowanie w sprawach nadzoru nad działalnościa komunalna, Warszawa 1995, s. 24-29, 78.

13 Sygn. akt II GSK 299/06, LEX nr 326273.

14 Sygn. akt I SA/Po 583/09, LEX nr 624269.

15 Sygn. akt I Sa/Ke 459/11, LEX nr 988300.

16 Sygn. akt I SA/Bk 151/12, LEX nr 326273.

17 Tak: W. Lachiewicz, Projekt ustawy o zmianie ustawy o regionalnych izbach obrachunkowych oraz niektórych innych ustaw. Diagnoza - projekt - uzasadnienie, Projekt „Systemowe Wsparcie Procesów Zarządzania JST”, Kraków 2014.

18 W. Chróścielewski, Z. Kmieciak, Postępowanie. w sprawach ..., s. 109. 
wiązania przyznają prezesowi Rady Ministrów, do którego kompetencji należy wprowadzanie zarządu komisarycznego, a także odwołanie organu wykonawczego i wprowadzenie w to miejsce osoby zastępującej ten organ; wojewodzie, któremu przysługuje prawo wydania zarządzenia zastępczego oraz kolegium regionalnej izby obrachunkowej, które upoważnione jest do dokonania zastępczego ustalenia budżetu oraz ustalenia programu postępowania naprawczego.

Artykuł 97 u.s.g., art. 84 u.s.p. i art. 85 u.s.w. wiąże ustanowienie zarządu komisarycznego w jednostkach samorządowych z przesłanką, ,nierokującego nadziei na szybką poprawę i przedłużającego się braku skuteczności w wykonywaniu zadań publicznych" przez organy gminy (powiatu lub województwa). Konsekwencją takiego stanu rzeczy może być zawieszenie przez prezesa Rady Ministrów działającego na wniosek ministra właściwego do spraw administracji publicznej, organów j.s.t. i ustanowienie zarządu komisarycznego na okres do dwóch lat, nie dłużej jednak niż do wyboru organu stanowiącego oraz wykonawczego na kolejną kadencję. Powołany komisarz rządowy przejmuje wykonywania zadań i kompetencji organów j.s.t. z dniem powołania. Ten personalny środek nadzoru ma jednocześnie charakter uznaniowy i, o ile jest wprowadzany, to dotyczy najczęściej samorządu szczebla gminnego.

Wprowadzenie komisarza (zgodnie z brzmieniem ustawy - osoby, która do czasu wyboru organu wykonawczego pełni jego funkcję) może nastąpić także na podstawie art. 96 ust. 2 u.s.g., art. 83 ust. 2 u.s.p., art. 84 ust. 2 u.s.p., w przypadku gdy wójt (zarząd powiatu lub zarząd województwa) dopuszcza się powtarzającego się naruszenia Konstytucji lub ustaw. Podjęcie tej decyzji przez prezesa Rady Ministrów następuje po uprzednim wezwaniu organu wykonawczego przez wojewodę do zaprzestania naruszeń i jeżeli wezwanie to nie odnosi skutku. Wyznaczenie osoby zastępującej organ wykonawczy następuje przez prezesa Rady Ministrów na wniosek ministra właściwego do spraw administracji publicznej. Powyższe rozstrzygnięcia nadzorcze prezesa Rady Ministrów podlegają zaskarżeniu do sądu administracyjnego.

7. Co do zasady wprowadzenie zarządu komisarycznego ma na celu właściwe realizowanie zadań publicznych. Teoretycznie nie musi się ono wiązać z istotnymi ograniczeniami możliwości rozwojowych danej j.s.t. W praktyce powołanie komisarza rządowego ma miejsce wskutek odwołania w drodze referendum wójta, burmistrza lub prezydenta miasta, albo gdy organ wykonawczy w sposób rażący narusza prawo. Natomiast w większości przypadków wprowadzenie komisarza jest skutkiem popadnięcia j.s.t. w kłopoty finansowe, które uniemożliwiają właściwe uchwalenie i wykonywanie budżetu. Przypadki takie mają miejsce przede wszystkim w małych gminach, gdzie na ogół funkcja kontrolna rady jest słabiej realizowana - co jest skutkiem gorszego merytorycznego przygotowania do wypełniania funkcji radnego, a organ wykonawczy odpowiedzialny za gospodarkę finansową na ogół nie poczuwa się do odpowiedzialności politycznej za istniejący stan rzeczy. 
Natomiast przypadki powołania komisarza na szczeblu powiatu zdarzają się niezwykle rzadko, a na szczeblu województwa praktycznie nie występują. Kolegialny charakter organu wykonawczego i jego duże upolitycznienie powoduje, że łatwiej i szybciej na tym szczeblu samorządu realizuje się odpowiedzialność polityczną ${ }^{19}$. Niewątpliwie również samorząd województwa ma większą siłę oddziaływania politycznego, która może zapobiec ingerencji premiera w postaci ustanowienia zarządu komisarycznego ${ }^{20}$. Bez względu na przyczyny ingerencji premiera, komisarz, obok umiejętności politycznych, winien również dysponować umiejętnościami merytorycznymi z zakresu zarządzania i finansów. Wojewodowie zgłaszający ministrowi administracji i cyfryzacji kandydatów na to stanowisko dysponują małą ilością lub wręcz nie dysponują kandydatami mogącymi spełniać postawione wyżej wymagania. Należy postulować, aby w każdym urzędzie wojewódzkim, w dyspozycji wojewody były osoby mogące w każdej chwili zastąpić odwołany organ wykonawczy.

8. Następny organ nadzoru - wojewoda ma prawo do wydawania zarządzeń zastępczych. Następuje to w przypadku, gdy organ stanowiący uchyla się od opracowania miejscowego planu zagospodarowania przestrzennego lub nie podejmuje uchwał, o których mowa w art. 6k ust. 1, art. 61, art. 6n ust. 1 i art. 6r ust. 3 ustawy o utrzymaniu czystości i porządku w gminach. Zarządzenie zastępcze może mieć również charakter personalny i odnosić się do przypadków, gdy właściwy organ (wójt, członek zarządu powiatu, członek zarządu województwa), narusza przepisy art. $383 \S 2$ i 6 oraz art. $492 \S 2$ i 5 ustawy z dnia 5 stycznia 2011 r. Kodeks wybor$c z y^{21}$ oraz art. 5 ust. 2 i 3 ustawy z dnia 21 sierpnia 1997 r. o ograniczeniu prowadzenia działalności gospodarczej przez osoby pełniące funkcje publiczne ${ }^{22}$.W takich przypadkach wojewoda wzywa organ j.s.t. do podjęcia odpowiedniego aktu w terminie 30 dni. Po bezskutecznym upływie wyznaczonego terminu, wojewoda po powiadomieniu ministra właściwego do spraw administracji publicznej wydaje zarządzenie zastępcze, na które przysługuje prawo skargi do sądu administracyjnego. Treść takiego zarządzenia wojewody dotyczy wygaśnięcia mandatu.

Brak terminu dla WSA, w którym powinna być rozpatrzona skarga na zarządzenie zastępcze wojewody, powoduje, że pomimo naruszenia prawa wójtowi

${ }_{19}$ Przykładem może być rezygnacja w dniu 12 grudnia 2012 r. marszałka województwa śląskiego w związku z tzw. aferą kolejową.

${ }^{20}$ Patrz: Apel radnych województwa mazowieckiego z dnia 14 kwietnia 2014 r. o wstrzymanie egzekucji ,janosikowego"; uchwała nr 156/14 Sejmiku Województwa Mazowieckiego z dnia 19 maja 2014 r. w sprawie apelu Sejmiku Województwa Mazowieckiego w sprawie działań nadzorczych Regionalnej Izby Obrachunkowej w Warszawie wobec aktów prawnych organów województwa mazowieckiego; protokół z posiedzenia Komisji Samorządu Terytorialnego i Polityki Regionalnej Sejmu nr 267 z 5 czerwca 2014 r. - http://orka.sejm.gov.pl/zapisy7.nsf/0.

${ }^{21}$ Dz. U. z 2011 r., nr 21, poz. 112 ze zm.

22 Dz. U z 2006 r., nr 216, poz. 1584 ze zm. Na temat odpowiedzialności z tego tytułu patrz: M. Jachimowicz, Odpowiedzialność karna za naruszenie przepisów ustaw samorządowych, „Prokuratura i Prawo" 2009, nr 7-8, s. 102 i n. 
(burmistrzowie, prezydenci miast) dalej sprawują swój mandat. De lege ferenda należałoby tu postulować wprowadzenie 14-dniowych terminów dla WSA do rozpatrzenia danych spraw, podobnie jak ma to miejsce w przypadku rozpatrywania skargi na wygaśniecie mandatu radnego - art. $384 \S 2$ kodeksu wyborczego. Inny problem ma miejsce w przypadku orzeczeń sądów karnych rozstrzygającymi o odpowiedzialności karnej osób piastujących funkcje publiczne. Sąd powszechny nie ma obowiązku zawiadomienia jednostki samorządu terytorialnego o wydanym wyroku. W praktyce powoduje to, że osoby skazane, którym winno się automatycznie wygasić mandat, jeszcze czasami piastują go przez kilka miesięcy. Może to mieć bardzo ważne znaczenie dla ważności podejmowanych przez organy stanowiące uchwał.

9. Kolejne z rozstrzygnięć nadzorczych o charakterze nadzwyczajnym dotyczy zastępczego ustalenia budżetu jednostki samorządu terytorialnego przez kolegium regionalnej izby obrachunkowej. W praktyce winno mieć to miejsce w następujących przypadkach:

a) kiedy organ stanowiący jednostki samorządu terytorialnego nie uchwali budżetu do dnia 31 stycznia nowego roku budżetowego;

b) kiedy organ stanowiący uchwalając budżet lub dokonując w nim zmian (co należy zarówno do kompetencji organu stanowiącego, jak i wykonawczego) naruszy ustawę o finansach publicznych i nie dokona autoweryfikacji uchwały (lub zarządzenia organu wykonawczego) w terminie wyznaczonym przez organ nadzoru;

c) kiedy organ stanowiący nie może uchwalić budżetu ze względu na niespełnienie wymogów art. 242 i 243 ustawy o finansach publicznych, tzn. kiedy j.s.t. przekroczy indywidualny wskaźnik zadłużenia wyliczony dla danej jednostki samorządu terytorialnego.

Przyczyny określone w punkcie a) i b) skutkujące nieuchwaleniem budżetu mają na ogół charakter polityczny i wynikają z braku porozumienia między organem wykonawczym i stanowiącym.

Przyczynę określoną w punkcie c) nazwałbym faktyczną niemożliwością uchwalenia budżetu ze względu na niemożliwość spełnienia relacji określonej w art. 243 u.f.p.

Przepis ten wprowadza indywidualny wskaźnik spłaty zadłużenia dla każdej jednostki samorządu terytorialnego ${ }^{23}$. $\mathrm{Z}$ jednej strony jest to rozwiązanie

${ }^{23}$ Konstrukcja spłaty zadłużenia z obecnego art. 243 u.f.p. różni się tym od poprzedniej wynikającej z ustawy z 30 czerwca 2005 r. o finansach publicznych tym, że w latach 2006- 2014 każda j.s.t. ograniczona była dwoma wskaźnikami - na podstawie art. 169 u.f.p. łączna kwota przypadających w danym roku budżetowym spłat kredytów i pożyczek, wykupu papierów wartościowych, potencjalnych spłat kwot wynikających z udzielonych poręczeń nie mogła być wyższa niż 15\% planowanych na dany rok budżetowy dochodów danej j.s.t. oraz na podstawie art. 170 u.f.p. łączna kwota długu nie mogła przekroczyć $60 \%$ wykonanych na koniec roku dochodów budżetowych. W chwili obecnej dla każdej z j.s.t. oblicza się na podstawie matematycznego algorytmu z art. 243 
sprawiedliwe,z drugiej strony poważnie ogranicza możliwości rozwojowe małych gmin. Wpływa również na możliwości absorpcyjne środków unijnych - nie muszą więc dziwić kolejne nowelizacje art. 243 ust. 3 ustawy o finansach publicznych wyłączające stosowanie ogólnej zasady dotyczącej wskaźnika zadłużenia wynikające z art. 243 ust. 1 u.f.p.

10. Dla właściwego wykonywania nadzoru nad jednostkami samorządowymi niezwykle istotna jest jasność i jednoznaczność przepisów, według których ten nadzór jest dokonywany. Brak tej jasności dotyczy, przede wszystkim, w ostatnich latach przepisów, na podstawie których Ministerstwo Finansów próbuje kształtować swoją politykę wobec samorządu terytorialnego w zakresie finansów publicznych. Wielokrotnie obiecywana reforma finansów publicznych praktycznie ogranicza się do kolejnych korekt - nie zawsze należycie opracowanej ustawy o finansach publicznych. W zakresie gospodarki samorządu terytorialnego najistotniejsze kwestie to: poziom długu, współczynnik spłaty tego długu, poziom deficytu, zapewnienie równowagi budżetowej, realistyczność prognoz finansowych ${ }^{24}$, poziom dochodów j.s.t. We wszystkich tych sprawach właściwym organem nadzoru pozostają regionalne izby obrachunkowe - jako organy nadzoru fachowego „w zakresie spraw finansowych". Obowiązujące przepisy wynikające z ustawy o finansach publicznych z jednej strony przyjmują rozwiązania, które mają ograniczać możliwość niekontrolowanego zadłużenia się j.s.t., $\mathrm{z}$ drugiej strony pozwalają niektórych wydatków obciążających budżety j.s.t. nie zaliczać do długu. Z punktu widzenia organów nadzoru, których działalność ma przede wszystkim zabezpieczać przestrzeganie prawa, istnienie norm wzajemnie się wykluczających godzi w istotę nadzoru i stawia pod znakiem zapytania pojęcie państwa prawa.

Nie ma wystarczających zakazów zadłużania się spółek komunalnych - co w efekcie powoduje obciążanie spłatami samorządu, czy pozyskiwania bardzo drogich środków zwrotnych od instytucji parabankowych ${ }^{25}$. Niestety do chwili obecnej nie stworzono w Polsce instytucji poręczającej kontrakty samorządów. Niektóre rozwiązania prawne rażą swoją fikcyjnością. Ustawodawca przykładowo w art. 126 u.f.p. stwierdza, że wieloletnia prognoza finansowa (dalej: WPF) winna

u.f.p indywidualny wskaźnik zadłużenia, biorąc pod uwagę dane dotyczące dochodów, wydatków, dochodów z mienia, rat spłat kredytów i pożyczek oraz odsetek z okresu trzech lat poprzedzających wskaźnik dla danego roku budżetowego. $Z$ jednej strony spłata rat kredytów może być wyższa niż $15 \%$ planowanych dochodów, z drugiej - faktycznie obniżyła się ona do około $9 \%$.

${ }^{24}$ Patrz: J. M. Salachna, Wieloletnia prognoza finansowa jako przedmiot kontroli i nadzoru regionalnych izb obrachunkowych, „Finanse Komunalne” 2010, nr10, s. 38 i n; S. Srocki, Wieloletnia prognoza finansowa jako instrument stabilizacji finansowej samorzadu - zagadnienia prawne, „Finanse Komunalne” 2014, nr 12, s. 5-14.

${ }^{25}$ Patrz wyrok SN z dnia 9 stycznia 2015 r., o sygn. V CSK 111/14, LEX nr 1622337, wskazujący, że poręczenie należności szpitala bez zgody organu nadzorczego - samorządu, jest nieważne. Wyrok choć kontrowersyjny daje pewną szanse na uzyskanie spójności ochrony finansów publicznych. 
być realistyczna, co przy opracowywaniu i uchwalaniu takich prognoz na okresy odpowiadające spłatom zobowiązań j.s.t., a więc nawet na okresy 30-, 40-letnie jest fikcją prawną - ponieważ dochody w praktyce dostosowuje się do potrzebnego wskaźnika. A więc prawnie próbuje się projektowane koncepcje idée fixe zrównywać z projekcją rzeczywistości. Artykuł 243 u.f.p., na którego podstawie ustala się tzw. współczynnik spłaty zadłużenia j.s.t., do jego wyliczenia przyjmuje wykonanie dochodów z dwóch lat poprzedzających obliczenie tego wskaźnika oraz $\mathrm{z}$ roku ostatniego - trzeciego. W tym ostatnim przypadku są to dochody planowane za trzy kwartały. Jest to swoista manipulacja danymi. Przykładowo w roku 2013 regionalne izby obrachunkowe wydały 64 negatywne opinie dotyczące projektów budżetów na rok 2014. Gdybyśmy planowane dochody zastąpili dochodami wykonanymi, to wówczas negatywnych opinii musiałoby być 378 . Oznacza to, że 13,7\% jednostek samorządowych w Polsce nie mogłoby uchwalić w 2014 r. budżetu ${ }^{26}$.

11. Jak wyżej podkreśliłem, nadzór nad samorządem terytorialnym w świetle art. 171 Konstytucji RP może opierać się wyłącznie na kryterium zgodności $\mathrm{z}$ prawem. Ustawa o finansach publicznych, wprowadzając w art. 126 wymóg realistyczności wieloletnich prognoz finansowych nie określa prawnych przesłanek, które mogłyby być brane pod uwagę przy ocenie tego wymogu. To oznacza, że niemożliwa jest pełna ocena prawno-faktyczna dokonywana na etapie postępowania nadzorczego, jak i sądowoadministracyjnego ${ }^{27}$. Rzeczywista ocena realistyczności musi być dokonywana na podstawie większą liczby kryteriów niż kryterium legalności. Ustawodawca, wprowadzając w 2009 r. pojęcie wieloletnich prognoz finansowych nie przesądził jednoznacznie o ich charakterze - czy wieloletnia prognoza finansowa jest uchwałą o charakterze prawno-finansowym, czy jest tylko normą planistyczną? Z jednej strony regionalne izby obrachunkowe mają możliwość stwierdzania nieważności tego rodzaju uchwał w przypadku ich sprzeczności z obowiązującym prawem, z drugiej strony nie przysługuje im prawo dokonywania ustaleń zastępczych, jak ma to miejsce w przypadku nieuchwalenia przez j.s.t. budżetu. Końcowym efektem stwierdzenia nieważności WPF może być funkcjonowanie j.s.t. bez wieloletniej prognozy finansowej, co wskazywałoby na planistyczny charakter tego aktu. Trzeba podkreślić, że stwierdzenie nieważności wieloletniej prognozy finansowej pociąga za sobą stwierdzenie nieważności uchwały budżetowej danej j.s.t. - odwrotna zależność nie występuje. Rozwiązania prawno-ustrojowe wprowadzone do ustawy o finansach publicznych

${ }^{26}$ Patrz: Kontrola koordynowana regionalnych izb obrachunkowych: Zadtużenie jednostek samorządu terytorialnego. Przestrzeganie ustawowych limitów zadlużenia i jego spłaty, Łódź 2014, s. 62, także posiedzenie Komisji do Spraw Kontroli Państwowej nr 132 z dnia 9 października 2014 r.

27 Takie stanowisko zajął WSA w Szczecinie w wyroku z dnia 18 grudnia 2013 r., sygn. akt I SA/Sz 1128/13 niepubl. oraz WSA w Warszawie w wyroku z dnia 11 marca 2014 r., sygn. akt V SA/Wa 262/14, LEX nr 1468329. 
w 2009 r. nie wydają się do końca logiczne, co w efekcie powoduje olbrzymie trudności dla prowadzenia działań nadzorczych przez r.i.o.

12. Zmiana charakteru wyspecjalizowanych organów nadzoru - regionalnych izb obrachunkowych, przekształcanie ich z organów nadzoru formalnoprawnego w organy nadzoru ekonomicznego. Zmiana ta jest konsekwencją wejścia w życie w dniu 1 stycznia 2014 r. ostatniej części regulacji wynikającej z ustawy z dnia 27 sierpnia 2009 r. - o finansach publicznych. Wprowadza ona tzw. indywidualny wskaźnik spłat zadłużenia jednostek samorządu terytorialnego poprzez ustalenie nieprzekraczalnych wysokości kwot przypadających do spłaty w danym roku budżetowym $\mathrm{z}$ tytułu długu jednostki samorządu terytorialnego. Jak zauważono w literaturze przedmiotu nadzorowanie przestrzegania tej zasady nie wymaga znajomości prawa lecz znajomości matematyki ${ }^{28}$. Zmiana zasad zadłużania się j.s.t. oraz dokonywania spłat zadłużenia została dokonana przede wszystkim w celu zahamowania przyrostu długu i deficytu jednostek samorządu terytorialnego. Sama idea - wprowadzenie indywidualnego wskaźnika zadłużenia była akceptowana i wcześniej postulowana jako wniosek de lege ferenda przez środowiska samorządowe. Natomiast zaproponowane rozwiązanie nie spotkało się z przychylną reakcją tego środowiska. Należy zauważyć, że rząd (Ministerstwo Finansów), proponując to rozwiązanie legislacyjne nie przedstawił dostatecznie uzasadnionych skutków społecznych i ekonomicznych przedłożonych do uchwalenia Sejmowi przepisów. Parlament nie otrzymał odpowiedzi na zasadnicze pytanie - jaka cześć samorządów nie będzie w stanie zaciągać nowych zobowiązań, a jaka nie będzie w stanie w sposób zgodny z ustawą spłacać zobowiązań już zaciągniętych? Odpowiedzi na przedstawione pytania w związku z potrzebą zagospodarowania przez j.s.t. kolejnej transzy środków unijnych miała zasadnicze znaczenie dla gospodarki finansowej j.s.t. Ukazywanie stosownych wyliczeń przez środowiska samorządowe i weryfikowanie tych danych przez regionalne izby obrachunkowe uświadomiły Parlamentowi pilną potrzebę zmian stosownych postanowień w nowej ustawie o finansach publicznych.

\section{Literatura}

Bober J., Hauser J., Izdebski H., Lachiewicz W., Mazur S., Nelicki A., Nowotarski B., Puzyna W., Surówka K., Zachariasz I., Zawicki M., Narastajace dysfunkcje, zasadnicze dylematy. Konieczne dziatania. Raport o stanie samorządności terytorialnej w Polsce, Kraków 2013.

Chróścielewski W., Kmieciak Z., Postępowanie w sprawach nadzoru nad działalnością komunalna, Warszawa 1995.

Dolnicki B., Nadzór nad samorządem terytorialnym, Katowice 1993.

Filipowicz A., Pojęcie i funkcje nadzoru w administracji, Wrocław 1984.

${ }^{28}$ Por. uwagi C. Kosikowskiego, Ustawa o finansach publicznych. Komentarz, Warszawa 2011. 
Jachimowicz M., Odpowiedzialność karna za naruszenie przepisów ustaw samorzadowych, „Prokuratura i Prawo" 2009, nr 7-8.

Kontrola koordynowana regionalnych izb obrachunkowych: Zadłużenie jednostek samorządu terytorialnego. Przestrzeganie ustawowych limitów zadłużenia i jego spłaty, Łódź 2014.

Kosikowski C., Ustawa o finansach publicznych. Komentarz, Warszawa 2011.

Krawczyk R.P., Efektywność i skuteczność nadzoru nad samorzadem terytorialnym, „Finanse Komunalne" 2014, nr 10.

Lachiewicz W., Projekt ustawy o zmianie ustawy o regionalnych izbach obrachunkowych oraz niektórych innych ustaw. Diagnoza - projekt - uzasadnienie, Projekt ,Systemowe Wsparcie Procesów Zarządzania JST", Kraków 2014.

Salachna J.M., Wieloletnia prognoza finansowa jako przedmiot kontroli i nadzoru regionalnych izb obrachunkowych, „Finanse Komunalne” 2010, nr 10.

Srocki S., Ewolucja kompetencji nadzorczych regionalnych izb obrachunkowych, [w:] M. Stec (red.), Regionalne izby obrachunkowe. Charakterystyka ustrojowa i komentarz do ustawy, Warszawa 2010.

Srocki S., Wieloletnia prognoza finansowa jako instrument stabilizacji finansowej samorzadu-zagadnienia prawne, „Finanse Komunalne” 2014, nr 12.

Wojciechowski E., Podgórniak-Krzykacz A., Dolewka Z., Wojciechowski M., Samorząd terytorialny $w$ Polsce. Raport, Łódź 2014.

\section{Orzecznictwo}

Postanowienie NSA z dnia 21 lutego 2007 r., sygn. akt II GSK 299/06, LEX nr 326273.

Postanowienie WSA w Białymstoku z dnia 27 czerwca 2012 r., sygn. akt I SA/Bk 151/12, LEX nr 1499842.

Postanowienie WSA w Kielcach z dnia 31 października 2011 r., sygn. akt I SA/Ke 459/11, LEX nr 988300.

Postanowienie WSA w Poznaniu z dnia 8 lipca 2009 r., sygn. akt I SA/Po 583/09, LEX nr 624269.

Wyrok SN z dnia 9 stycznia 2015 r., sygn. akt V CSK 111/14, LEX nr 1622337.

Wyrok TK z dnia 18 lutego 2003 r., K 24/02, OTK 2003, nr 2, poz. 11.

Wyrok TK z dnia 5 października 1994 r., W 1/94, OTK 1994, nr 2, poz. 47.

Wyrok WSA w Szczecinie z dnia 18 grudnia 2013 r., sygn. akt I SA/Sz 1128/13, niepubl.

Wyrok WSA w Warszawie z dnia 11 marca 2014 r., sygn. akt V SA/Wa 262/14, LEX nr 1468329. 